\title{
A disciple of Whitman and Ruskin: William Harrison Riley, transatlantic celebrity, and the perils of working-class fandom
}

Mark Frost

\section{Abstract}

This article focuses on the attempts of working-class intellectual, William Harrison Riley, to act as a transatlantic bridge between two of his literary heroes, John Ruskin and Walt Whitman, and on what this reveals about the operations of nineteenth-century celebrity culture. Exploring the ways in which Ruskin and Whitman constructed public profiles as generational prophets or seers, the article suggests that in some ways these figures sought to escape the traditional dynamics of celebrity construction, but in other ways exploited or reinforced them. Stressing their credentials as democratising figures who could connect to the working classes, Whitman and Ruskin simultaneously pursued rhetorical strategies that also stressed their own exceptional status. In both cases, their lofty elevation relied upon the existence of disciples, while seeming to offer these disciples the opportunity to transcend fandom and the fundamental hierarchical principles underlying celebrity culture. In this context, William Harrison Riley is of particular interest as a working-class writer who sought something like equality with Ruskin and Whitman, both by joining Ruskin's Utopian Guild of St George, and by trying to negotiate Ruskin's support in raising Whitman's British profile. The costly failure of his enterprises reveals how problematical it is to attempt to overturn the hierarchies of celebrity and fan, and suggests that celebrity is a reflection within literary culture of wider social stratification in nineteenth-century consumer capitalism. 
In January 1879 two visitors called at Brantwood, the Lakeland home of John Ruskin, a man who sat at the top table of Victorian fame. The first, Henry Salt, is known as a biographer, social campaigner, vegetarian, animal rights advocate, and the man who introduced Gandhi to Henry David Thoreau's works. An Eton Assistant Master with a public school and Cambridge background, his passing entry into the Ruskin circle was straightforward. The other visitor, William Harrison Riley, a self-taught working-class intellectual and writer, lacked Salt's social connections or experience of elevated society. The visit, briefly described in Salt's memoir, underlined Riley's subordinate status:

I accompanied Riley to luncheon at Brantwood, and was greatly struck by the meeting between the two - the devotion of the follower, and the geniality of the sage ... Riley, who was much surprised by the luxuriance of the verdure at Coniston, as compared with the grey desolation of the Sheffield hills [where he lived] confided to me his intention of taking as a present to Ruskin a clump of moss from a wall-top near the hotel; but as there was hardly a wall in the district that was not similarly covered, I suggested to him, as delicately as I could, that it might be a case of carrying 'coals to Newcastle.' Disregarding such hints, he arrived at Ruskin's door with a big parcel of the moss, and gravely presented it as soon as the first salutations were complete. The delightful charm of Ruskin's manner was seen in this little incident: he laughed - for who could have helped laughing? - yet took the gift - and turned the subject - with a graciousness that could leave no hurt. ${ }^{1}$

This unconsciously condescending recollection of the gracious sage and the gauche disciple served to demonstrate Ruskin's social superiority, but Salt never pauses to consider Riley’s 
motivations. As will become clear, Riley had pressing reasons for establishing cordial relations with Ruskin, and his singularly appropriate present carried a message that he understood Ruskin more profoundly than Salt and sought to deepen their connection. 'Moss', the opening chapter of Proserpina (1875-86, 2 vols.), one of several works Ruskin was serializing at the time, represented a typically acute reading of the significance of humble natural phenomena. ${ }^{2}$ In presenting moss to Ruskin, Riley was presenting himself as someone who shared Ruskin's convictions about the sacred lessons of divine nature, and making a claim for intellectual rather than social kinship that, he hoped, would permit him to be more than simply a fan of a leading celebrity. If he failed to gain entry into Ruskin's circle it was not for want of understanding, but while Ruskin may have lauded the humble moss he could not embrace the working-class acolyte. Riley, in turn, could not overturn his subordinate status within nineteenth-century celebrity culture.

The son of a Manchester fustian cutter and lay preacher, Riley was one of a growing number of working-class activists who pursued famous figures in order to support their own political and literary enterprises. Recent scholarship has examined a constituency of Lancashire followers of Walt Whitman who sought to translate the poet's message in a specifically British context. Although unconnected to them, Riley should be recognized as a significant figure amongst British Whitmanites. ${ }^{3}$ A Christian Socialist and member of the Internationale, he was inspired by Marx and co-operativism, but his politics were reshaped during a second period of residence in America during the 1860s, when he eagerly absorbed Republicanism and the democratising ideals of Whitman's poetry. Returning to Britain in 1870, he led mutual aid groups, edited several short-lived socialist newspapers, and published two pamphlets, including the suggestively-titled Yankee Letters to British Workmen (1871). ${ }^{4}$ A truly transatlantic figure - Riley returned to the States in the 1880s, living there until his death in 1907 - his politics sought to synthesize American and British radicalism, and to 
bring together two men - Ruskin and Whitman - whose social visions, he believed (largely erroneously) were aligned and who were capable of establishing the new age of enlightenment to which he aspired. Seeking to position himself as a transatlantic conduit connecting the two men, Riley hoped to achieve something like equality with them, and in doing so to bypass the hierarchical dynamics of celebrity culture. I will explore the connections between Riley's failure as a transatlantic bridge and of his attempts to become an established leader within Ruskin's utopian ventures because both reveal the limits often placed on working-class attempts to enter elevated circles, and about the ways in which celebrity is a public act that depends both on the self-construction of the celebrity and on the existence of those eager to participate in such constructions. While many celebrity studies point out the enormous pressures placed on celebrities by fan culture, fans could also be bruised by such encounters. Riley's correspondence reveals that he suffered exclusion and privation as a result of his interactions with Ruskin, and that his attempts at agency, as fan, activist, and writer were ultimately blighted.

This article, like Riley, exists in an awkward but productive hinterland between two orbits the circles of Ruskin and Whitman. While literary celebrity was nothing new, as the careers of Dr Johnson, Sir Walter Scott, and Lord Byron attest, the nineteenth century witnessed a rapid expansion of this phenomenon. ${ }^{5}$ As Charlotte Boyce, Páraic Finnerty, and Anne-Marie Millim argue, public recognition of celebrities became 'an industrialised, institutionalised and commercialised process that normalised and legitimised the desire for cultural visibility, along with the idea and existence of identifiable figures whose function it was to circulate within an expanding and pervasive mass media and mass market'. ${ }^{6}$ The value of celebrity studies lies not in providing stable categories of fame, but in the opportunities it opens up for exploring the wider socio-economic dynamics of celebrity culture. David Haven Blake is 
sceptical about the way in which some celebrity scholarship attempts to distinguish 'fame to signify real and lasting accomplishment and celebrity to describe the meretricious notoriety they see as being prevalent today'. ${ }^{7}$ Leo Braudy typifies the position that fame (enduring renown) can be distinguished from celebrity (short-lived notoriety), but Brenda R Weber sees the distinction as 'rather porous, since it is not always clear what constitutes the legendary stuff of fame as distinct from the momentary fluff of celebrity': the genius, the famous figure, the literary lion, and the deserving and underserving celebrity repeatedly appear in such discourses, but such distinctions are in practice impossible to maintain. ${ }^{8}$ More usefully, however, they point to persisting anxieties about whether fame could been achieved simply by using self-promotional techniques to exploit the supposed fickleness of popular opinion. Such anxieties continued throughout the century (and beyond) and were variously evident in the profiles of the two figures that Riley hoped to connect.

Sharing Haven Blake's scepticism about terminology, I would argue that it is helpful to note two other features of celebrity culture: firstly, the sheer variety of possible forms that fame can assume, and, secondly, the vital role played by non-celebrities in the construction of celebrity. Nineteenth-century celebrity, Richard Salmon argues, relied on enhanced promotional and dissemination opportunities offered by technological advances in printing and photography, and on the helpful effects of copyright laws, but he points out that these were not sufficient 'to secure the cultural authority desired by many writers of the time' because professionalization 'also required a change of consciousness, of internal "selfdefinition", among authors, which could be mediated as a higher level of professional authority'. ${ }^{9}$ But changes of consciousness were also occurring amongst the non-celebrities who helped make celebrity possible. In a brilliant study of mid-Victorian fame culture, Nicholas Dames contends that 'brushes with fame' affect the non-celebrity and wider culture to such an extent that 'celebrity as a rhetorical and cultural figure becomes a sign for reality 
itself', a cultural guarantor of 'the real'. For Dames, the 'perfect reality-effect' of celebrities means that in a consumer culture we 'borrow our sense of reality from the celebrity' so that 'when we meet one, we have reality conferred upon us' ${ }^{10}$ If the celebrity is to succeed as 'a rhetorical and cultural figure' they must do so in public and with the active participation of a constituency of admirers or fans. The cultural elevation of the celebrity inevitably relies upon a concomitant process of cultural subordination of those who settle for some degree of vicarious access to celebrity lives. In complex ways, this process of cultural elevation was a key feature of the public lives of Ruskin and Whitman, figures who engaged in very different ways with the dynamics of celebrity. Riley's attempts to experience more than a 'brush with fame' and to achieve a profound connection with his heroes, was a fascinating, but ultimately futile challenge to a dynamics of celebrity construction that reflected the widening social stratification of nineteenth-century capitalism. With instructive similarities and differences, Whitman and Ruskin represent significant examples of the construction of a particular species of nineteenth-century literary fame - a type we might describe as the generational prophet, seer, or sage - and both reveal the vital role played by followers in the establishment of this type. Charismatic and astute, both courted particular audiences, and attracted ardent disciples whose interest in their respective authors transcended the literariness of their work while elevating the status of the authors in ways that seemed at times to destabilize the hierarchical dynamics of celebrity culture.

Ruskin and Whitman subsumed literature to the cause of social change and, following Thomas Carlyle and Ralph Waldo Emerson, pursued the status of lofty interpreters of present ills and heralds of the future. Distinguishing Whitman's approach to celebrity from traditional aspirations for poetic immortality, Haven Blake suggests that he 'added a new sense of fame ... in relation to the crowd', in which 'readers would not simply attend to the poet's work', but 'would be attracted to the magnificence of his personality' and 'would see 
in his poems a vibrant cultural performance, an individual springing from the book with tremendous charisma and appeal'. ${ }^{11}$ Whitman insisted that 'religious purpose' was his principal motivation, and that 'no one will get at my verses who insists upon viewing them as a literary performance ... or as aiming mainly towards art or aestheticism', but his public life was nonetheless highly performative, and his approach simultaneously and perhaps paradoxically stressed his status as everyman and prophet. ${ }^{12}$ In a study of Whitman's small band of disciples, Michael Robertson suggests that they 'were ready to regard Whitman as a successor to Jesus, Kronos, Buddha, and every other religious figure of the past because of the widespread openness at the time to the concept of the poet-prophet'. ${ }^{13}$ One of these disciples, John Burroughs, typically insisted that 'lovers of Whitman no more go to him for poetry than they go to the ocean for the pretty shells and pebbles on the beach': Leaves of Grass 'is not poetry as the world uses that term [but] an inspired utterance'. ${ }^{14}$ Whitman's poetry reflected and shaped 'the progressive optimism common among nineteenth-century spiritual seekers, the notion that earlier religions had been rough sketches for a fully realized democratic spirituality that was manifested equally in every man and woman', but despite the equalising impulses of Whitman's vision, he used promotional techniques to underline his own exceptionalism. ${ }^{15}$

Whitman's promotion of a messianic persona involved actively courting celebrity. A late starter in poetry, and with a family to support, the working-class Whitman had pecuniary as well as egotistical reasons to engage in flagrant self-promotion. In 1855 he received a letter from Emerson that described Leaves of Grass as 'the most extraordinary piece of wit and wisdom that America has yet contributed' and closed with the words 'I greet you at the beginning of a great career'. ${ }^{16}$ To Emerson's displeasure, Whitman publicized the letter and included it in subsequent editions of Leaves of Grass. Whitman believed in his own significance and unhesitatingly exploited Emerson's powerful imprimatur. So integral was 
self-promotion to Whitman's poetic persona that one contemporary admirer, William Thayer, worried that Whitman had become 'a poseur of truly colossal proportions, one to whom playing a part had long before become so habitual that he had ceased to be aware that he was doing it', while Haven Blake has dubbed him 'the Muhammad Ali of American literature, the man whose bombast and epithets were so overwhelming that they had gloriously taken root'. ${ }^{17}$ As Robertson and Haven Blake both point out, he adeptly used photography to promote 'his mature style: long hair and full beard, wide-brimmed hat, open-collared shirt working class with a bohemian flair', and self-consciously projected 'the image of benign wisdom that the disciples sought in a spiritual master'. ${ }^{18}$

With some justice, Riley regarded himself as one of the poet's first British disciples. He read Whitman in 1867, in Boston, two years after John Addington Symons obtained an 1860 edition of Whitman's Leaves of Grass, and a year before a fourteen-year old Oscar Wilde read William Rossetti's expurgated 1868 edition. ${ }^{19} \mathrm{He}$ appears to have been particularly attracted by Whitman's democratising impulses, as he told another working-class intellectual in 1891, placing the poet alongside other nineteenth century prophets:

I am not competent to judge as to the relative greatness of Whitman and Emerson in writing, but always feel like bracketing them together, with Thoreau as a third. Of modern English writers, I place Carlyle first, without any guess about a second. If the four named, each is first by far, in his own special line, Whitman is the most difficult to understand, by new readers, but, I think, has greater [sense] than any other writer I know of.

Riley's elevation of the autocratic Carlyle reflects the irresolvable paradox of his attempts to bring together Ruskin and Whitman - the former insisting in Carlylean fashion on limits to 
the abilities, social mobility, and political franchise of the working classes, the latter seeking their full democratic participation. Riley was also attracted by the manner in which Whitman's principles appeared to be grounded in practice:

Whitman was no 'easy chair philosopher'. He worked as a carpenter, and set the Type for his first edition of 'Leaves of Grass". He worked in the hospitals. His 'Democracy' means you - 'yourself, yourself, yourself - for ever and ever'. He makes as little of Presidents as Kings. He sings the song of Personality, and looks with most satisfaction on such lands and societies as tend to develope [sic] better man and women. ${ }^{20}$

Whitman's enduring influence fed Riley's hopes for a Christian socialist republic, and Whitmanite spirituality was evident in advice Riley proffered in 1876 to a recently bereaved friend:

The body is always unceasingly dying, yet identity continues through all the dying - through all the casting off of bodies. It as surely continues, even when the body dies all at once ... Through innumerable ages of physical and psychical change + advancement - you have arrived at the culmination - the chief stage of existence on this earth. The next advance must be a new birth in a fresh sphere - suitable, fit for you. ${ }^{21}$

This transcendent vision echoed Whitman's lines in 'Song of Myself':

And if ever there was it led forward life, and does not 
wait at the end to arrest it,

And ceas'd the moment life appear'd.

All goes onward and outward, nothing collapses,

And to die is different from what any one supposed, and luckier. ${ }^{22}$

While Ruskin's public profile also developed towards prophetic status, his attitude to celebrity was quite different. Amongst the most prominent of all Victorians, Ruskin achieved fame in his twenties, but found celebrity distasteful. Protected by his father's wealth, Ruskin's amateur-gentleman status insulated him from the commercial imperatives pressing on the lives of professional authors. Although he achieved a level of celebrity of which Whitman would have been envious, Ruskin maintained an elevated distance from celebrity culture, and shared a broader nineteenth-century disquiet about the rise of celebrity, particularly evident in debates about the 'literary lion'. The lion stood for 'the distorted, inflated, comically and frighteningly toothsome image of public notoriety', and was often characterized 'as a flagrantly narcissistic and prematurely ageing male dandy' whose celebrity was inevitably short-lived - a function of the excessive, faddish appetite of a modern capitalist market and the perceived flightiness of an ill-informed reading public: 'the cultural practice of lionism', Salmon argues, 'signals the fungible status of modern authors, each successive "lion" replacing the temporary renown of his predecessor'. ${ }^{23}$ While Whitman's self-promotion carried echoes of lionism, Ruskin, the reluctant celebrity, hoped intrinsic value, rather than temporary notoriety, would establish his reputation. His first work, The Poetry of Architecture (1837-8), was published under the pseudonym Kata Phusin (Greek, 'According to Nature'), while first editions of Modern Painters I (1843) were attributed to 'a Graduate of Oxford'. To his disgust, his early status as an aesthetic celebrity 
rested at least as much on his dazzling prose as on his message about the transformative possibilities of engagement with art, architecture, and divine nature. Although familiar with the mechanisms of fame, Ruskin's distaste for celebrity culture grew as he aged. After 1860, as his work became more directly political, his celebrity was undimmed, and perhaps even enhanced, as he became increasingly notorious for unrestrained attacks on liberal capitalism. In a process of reconstruction as a prophet reviled by his generation but offering salvation to those willing to heed his High Tory anti-capitalism, Ruskin's later rhetorical strategies often meant attracting a core band of adherents by alienating others. As George P. Landow argues, he adopted 'a form of non-fiction that adapts the techniques of the Victorian sermon, neoclassical satire, classical rhetoric, and Old Testament prophecy to create credibility for the interpretations of contemporary phenomena made by a figure, the sage, who stands apart from his audience and society' because of singular interpretative abilities. ${ }^{24}$ Presenting a pronounced division between mainstream stupidity and prophetic insight, Ruskin invited readers and audiences to choose: those who stood with him constructed themselves as faithful disciples in a battle between good and evil. A household name whose celebrity notoriety only increased as he rejected liberal consensus, his alternative self-positioning as sage rested on presenting himself as an exceptional figure, but also on offering special access to 'worthy' adherents (those willing to go beyond 'fandom'). As we shall see, however, there were significant limitations (and hazards) to this access.

In 1871, Ruskin's establishment of the Guild of St George, conceived as an alternative society of environmentally sustainable agricultural estates that would challenge the steam-fuelled dragons of Victorian modernity, asked fans to become activists by joining this quasi-monastic organisation. As John D. Rosenberg notes, Ruskin used Fors Clavigera: Letters to the Workmen and Labourers of Britain (1871-83, 5 vols) as a mouthpiece for the Guild: 
The letters directly address the affairs of this small band of followers, giving the series a distinct if unnoticed kinship to the pastoral Epistles of the New Testament. Travelling widely over western Europe and the Mediterranean, proselytizing for the Guild in the pages of Fors and preaching his message of co-operation and compassion, addressing the members as their 'Master' and expounding on virtually every verse in the Bible, Ruskin writes like a quixotic St Paul who stayed in all the best hotels. ${ }^{25}$

The embattled nature of Ruskin and his small 'diaspora of kindred spirits' (Rosenberg 127) reinforced their bonds, and gestured to a model of interaction that went beyond the traditional dynamics of celebrity and fan, but at the same time Ruskin remained the exceptional figure the privileged Pauline messenger in search of listeners. The subtitle of Fors sought to underline Ruskin's influence over the working classes, but its rhetorical strategies involved simultaneously reaching out to them and underlining his own superiority. His elevation was doubly signalled by the titles by which he was known after 1870: he was both the autocratic 'Master' of the Guild and, after his elevation to Oxford's Slade Professorship of Art in 1870, 'the Professor'. Reaching out to audiences in Oxford and the industrial cities of Britain, the masterly professor made considerable demands on potential followers. To be a devoted Ruskinian after 1870 involved effort and determination, not least because his new publishing company, George Allen \& Co, in crusading against the self-enriching strategies of the Victorian book trade, eschewed substandard production techniques, advertisements, and trade discounts. Works like Fors Clavigera were as a result relatively hard to obtain, difficult to read, and expensive to buy. Dismissing readers' complaints in Fors that the monthly letters were 'almost unknown to those to whom you have addressed them', Ruskin answered that 
'you will hear of Fors, so, in time; - if it be worth hearing of' ${ }^{26}$ Intrinsic value, rather than vulgar promotion, would guarantee whatever success it achieved. After a slow start, Fors sold well, and its claim to reach workers was reinforced by the institution of a 'Notes and Correspondence' section in which readers' letters, including many from working-class readers, were published. Maintaining editorial control, and often rubbishing readerly contributions, Ruskin nonetheless permitted readers to eagerly critique his authoritarianism, the obscurity of the letters, and their cost. Opening space for dissent, this daring experiment moved political activism from a purely monological mode, making Fors a major vehicle through which Ruskin constructed himself as a public figure accessible to those who engaged with his ideas rather than his celebrity. The smaller number of Fors readers who became Guild Companions often achieved even greater personal access, including correspondence opportunities, visits from the Master, and Brantwood invitations. Ruskin's relocation there in 1872 meant withdrawal from the celebrity whirlpool of London and the opportunity to better control access to himself. Brantwood's rootedness in Romantic landscape, its distance from the main hubs of British society, and its elevation above Coniston Water, made Brantwood an attractive symbol of Ruskin's lofty sagacity. Like Tennyson's Farringford and Tolstoy's Yasnaya Polyana, this was a major site of cultural pilgrimage. ${ }^{27}$ To Ruskin's disciples a Brantwood visit was often recalled as a rare mark of personal distinction, although such visits were a relatively frequent occurrence before Ruskin's mental health declined in 1878 .

In some important respects, Ruskin's engagement with Guild Companions offered an alternative model to superficial encounters with celebrity, but important caveats should be added to this assessment. Inspired by Fors, a number of working-class men offered themselves as settlers on the Guild's agricultural estates, feeling that they had been specially chosen as idealists willing to put their lives at Ruskin's service, and to whom would be granted the profoundest connection to him. These vulnerable Companions found instead that 
Ruskin's image as a friend of labour conflicted with his Carlylean authoritarianism, and that their distant idol neglected them as they laboured in poor conditions under unscrupulous local agents. So far from being the reformative pastoral idyll conjured by Ruskin in Fors, their experiences were largely of isolation, poverty, and despair. Worse still, the stories of these lost Companions have until recently been distorted or concealed from history because of a campaign by leading Guildsmen to cover up the disastrous management of Guild lands and to protect the ageing Master's reputation. ${ }^{28}$ Riley was prominent amongst these lost Companions, and his experience of Guild life on its St George's Farm estate at Totley, near Sheffield, was typically painful, but in other ways he was a far more cosmopolitan figure than most Companions, and his transatlanticism leant him credibility as a potential connector of his literary heroes. Riley has long been maligned as the cause of the demise of St George's Farm but neglected archival sources suggest that his culpability is far from clear, and that he was manipulated by Ruskin's manager at the farm. ${ }^{29}$

I am suggesting, then, that Riley's 1879 Brantwood visit occurred at a delicate moment, in terms of his vulnerable position as a Guild settler and of his attempts to forge connections between Whitman and Ruskin. That Riley was still unsure of his situation is surprising given that he and Ruskin had been corresponding for eight years. Riley was an avid correspondent and his collected papers include letters from William Rossetti, Karl and Elinor Marx, Edward Carpenter, Walter Besant, and Rudyard Kipling. Like other impecunious correspondents Riley raised money by selling off famous signatures, and in the Ruskin-Riley correspondence there are moments when both writers perceived the potential value of their exchanges. Ruskin closed an 1878 missive to Riley with the words 'written with Sir Walter Scott's pen', to which Riley appended a note that read 'written by Ruskin a few hours before an attack of brain fever' ${ }^{30}$ Both highlight the singularity - and hence value - of this recorded moment. 
That literary artefacts could be co-opted as part of the broader construction of celebrity culture was well-established by this time, but the value of celebrity correspondence went beyond finance. Many of Ruskin's later followers - including those with relatively superficial links - exploited their connection by publishing privately printed editions of their correspondence: these expensive limited editions, ostensibly for private circulation, made very public claims about the correspondent's cultural capital. ${ }^{31}$

The Ruskin-Riley correspondence reveals much about the ways in which Riley misinterpreted Ruskin's politics, and the ways in which Ruskin sought to control his disciple's views. As early as 1873 , Ruskin informed Riley that 'I am greatly interested, as always, in your letters, while they much grieve me'. Going as far as to declare Riley 'thoroughly honest' and to 'accept now which I have not hitherto done, the title of your friend', he demurred at promoting Riley's 'present plan', probably one of Riley's schemes for model socialist villages. A warming in relations ensued: 'I begin to get very much intrigued by your letters, they are so well meaning - and so good-humoured - and so deep in essential feeling', Ruskin told him during this period. The sage was attracted by Riley's intelligence, but troubled by his socialism, condescendingly suggesting that 'I believe myself wiser than you, and will only help you (if I do), as I would a child to make an experiment, which I knew would fail, but in the failure teach him'. ${ }^{32}$ Ruskin felt at times that he had succeeded in crushing integral parts of Riley's Whitmanite socialism: 'I see that to a certain extent, we agree', he wrote in 1873, 'and that you are now prepared not to speak of Republicanism till you have taught the working men Self Respect ${ }^{33}$ However, their correspondence remained a struggle between two strong political visions, a wary circling, and a thwarted desire to connect. While Riley hoped Ruskin's wealth and influence would enable his plans for socialist co-operation, Ruskin sought to steer Riley towards his own conservatism. Neither 
prevailed, but Riley's attempts to use Ruskin's celebrity for his own ends and in order to assist Whitman in the U.K. came at a very high ideological and personal cost.

In 1878 a formal alliance was forged when Riley was appointed manager of St George's Farm. ${ }^{34}$ Riley's brief tenure there was perhaps the most hopeful phase of his life. Riley told a correspondent that he understood and submitted to Ruskin's politics: 'St George is supposed to be Intelligence, Virtue, Justice, and his work is to destroy the "Dragon" Ignorance, Vice, Injustice'. The Guild 'desires to teach people how to earn their living honestly, and to enjoy their living - to teach them the art of enjoying life, by earning enjoyment; to teach people how to govern and to be governed'. Despite this, he confided that he retained radical plans for model villages, newspapers, and revolution. Sceptical of Ruskin's authoritarianism, Riley opportunistically aspired to do good on his own terms, but ran the farm efficiently and took to agricultural life, relating that he was 'proud of my work, and feel much inclined to show off over much when I go to town in my hob-nails. ${ }^{35}$ It was highly distressing, therefore, that in August 1878 Ruskin abruptly installed his own gardener, David Downs, as farm manager. The suddenly-demoted Riley argued that Ruskin had broken their written agreement and appointed a man whom he described as a drunken crook and opponent of Guild values. Their co-tenure of the farm was characterized by bitter animosity. In January 1879, then, as Riley prepared to meet Ruskin for the first time, a great deal rode upon that gift of moss, for he still hoped to be reinstated as farm manager and to achieve a leadership role within the Guild, but his aspirations were dashed a year later when Downs connived to have Riley dismissed. Virtually penniless, Riley emigrated to Massachusetts, telling a correspondent in 1889 that 'during 30 years varied and busy life, I have never never been pained and deceived by any other person so much as by John Ruskin' ${ }^{36}$ The greatest complaint amongst various letters recalling this unhappy period, however, was the repeated accusation that Ruskin had destroyed an opportunity to connect with Whitman. 
At Totley, Riley met Edward Carpenter, the poet-activist who had established himself as a university extension lecturer, and who, as Riley reverently noted, 'actually went to America to see Walt Whitman - after reading his wonderful poems' ${ }^{37}$ Carpenter and Riley moved within supportive radical networks in northern England, and were part of growing constituency of British Whitman disciples who regarded the American as prophet of a new age of enlightenment. ${ }^{38}$ While Carpenter's confidence, education, and independent wealth helped gain access to Whitman's inner circle, the working-class Riley's desire to engage with the American poet was beset by obstacles. His intense discipleship is clear in letters written to Whitman from St George's Farm a few months after that Brantwood visit. In spring 1879 Riley wrote three adoring letters to Whitman, addressed to 'my dear friend and master', in which he described Leaves of Grass as 'a Revelation':

No words will serve to indicate the value your living words have been to me. In all my trouble and successes I have been strengthened by your divine teachings. You are not only inspired yourself, but you inspire others ... I have never faltered in my faith and love, and have always esteemed you as the Messenger of this age. (My words seem utterly paltry and drivelling, and I am thoroughly ashamed of them. But you know what I desire to utter.)

Speaking breathlessly of Whitman's influence, Riley adopted the intense tone and vocabulary familiar in Whitman discipleship:

Since I read your book I have been striving to work as a good pupil and companion. You have sent me through poverty and many cruel tribulations, but I have never whined over my work. ... Out of the strife, through the 
poverty ... I came out clean handed and clean hearted - always supported by your great teachings. My dear Master, do write to me, your faithful pupil and lover. My words will not prove my love, but could you have seen my work since I first read your divine message, you should know I loved you, and that you had gained one more loving soldier for your campaign.

Emulating Whitman's celebration of manly comradeship and labour, Riley's desire to become part of the world of the writer who had 'translated hitherto hidden languages for me' rode upon the influence he claimed to have with Ruskin, and sought to displace the familiar hierarchies of fandom and celebrity with a triangulation of equals. Requesting photos and a first edition of Leaves of Grass, Riley promised to send them to Ruskin, 'a Master and a Man eminently just and brave' whose 'utterances are always classical, and mostly divine'. Positioning himself between celebrities, and brokering contact, he delightedly reported Ruskin's reaction to 'a few extracts of your poems' that Riley had sent: 'though he was ill, he at once answered, as follows: "Dear Riley, These are quite glorious things you have sent me. Who is Walt (Walter?) Whitman, and is much of him like this [?]"'. Insisting 'that Ruskin is esteemed as the greatest critic of scripture, sculpture, and painting that we have any knowledge of', he told Whitman that when 'he writes "glorious," [he] means really the utmost degree of excellence'. ${ }^{39}$

Although agreeing to Riley's request, Whitman was apparently less excited than Riley by Ruskin's imprimatur. They were hardly natural allies, after all: Whitman's democratising disgust for organized religion was associated with a distaste for European feudalism, while Ruskin rested his entire social and aesthetic vision on valorizing mediaeval culture, and was deeply critical of democratic politics. The conservative Ruskin approved the extracts of Whitman's poetry Riley had sent, but closer inspection may have led him to join 
those who judged his verse immoral. Whitman believed in the providential role of the United States in forging a new kingdom of God, while Ruskin disparaged the former colony, campaigned against unauthorized American editions of his works, and told Fors readers that 'though I have kind invitations enough to visit America, I could not, even for a couple of months, live in a country so miserable as to possess no castles' ${ }^{40}$ While Riley may have made a perfect transatlantic bridge, there is little reason to suspect that his two idols would experience a profound meeting of minds. ${ }^{41}$

A month after his request, Riley acknowledged receipt of the book and photographs and eulogized Ruskin as 'a great, good man ... not only a beautiful writer, but a beautiful worker [who] will always $d o$ what he thinks he should do, even at the hazard of death or disrepute'. ${ }^{42}$ Two days later Riley relayed Ruskin's response: 'I am very glad to know that I can give some pleasure to such a man. I will write to him directly. Send the book to Brantwood. All you tell me is more frightful than I care to write of'. Working with outdated information, Riley had informed Ruskin that Whitman 'had been dismissed from office in Washington, and that the American publishers will not publish [his] works' ${ }^{43}$ Thrilled by his apparent success, Riley was confident that Ruskin would use his celebrity cachet to promote Whitman in Britain, and perhaps, in doing so, to draw Riley more closely into this transatlantic alliance. ${ }^{44}$ As he later confided to a fellow Companion, what happened next devastated him:

I wrote and told Whitman of the promise and Whitman sent - through me, copies of his works for Ruskin. Well, several months afterwards Ruskin came to Totley and I asked him if he had written to Whitman and he said 'no'. ${ }^{4}$ 
In a painfully ironic footnote it appears that Ruskin did contact Whitman, but in a way that entirely failed to acknowledge Riley. Less than a year after Riley's Brantwood visit, and eight months before Riley was dismissed from Totley, W. J. Bathgate of Cheshire wrote to Whitman to pass on Ruskin's admiration and a cheque for five copies of the latest twovolume edition of Whitman's works. Bathgate reported that Ruskin had described Whitman's works as 'deadly true - in the sense of rifles - against all our deadliest sins', and had expressed 'his utter astonishment at what I had told him about your pecuniary position, which he read of first in an article of mine' ${ }^{46}$

Ruskin may have deliberately snubbed Riley, or Ruskin's psychiatric disorders after 1878, and sheer pressure of work, may have led to forgetfulness, but for Riley the situation was unforgivable. His forlorn campaign had merely revealed his insignificance to the Brantwood sage: his Guild discipleship had met with summary dismissal, while his desire to connect his literary heroes meant little to Ruskin. Riley longed to meet Whitman, to be recognized as a fellow writer, and to transcend fandom altogether, but Ruskin's actions had crushed these dreams. Riley's attempted entrée to Whitman's circle rested on a chimerical claim to have influence with Ruskin, a writer for whom the American poet had little appetite. Riley's attempts to enter the Ruskin circle had meant compromising elements of his own ideology, and had resulted in poverty, betrayal, and misery, while his aspirations to literary equality had meant only continued subordination in the world of letters. To be a workingclass fan with aspirations was to run up against an entrenched class system and the power structures of celebrity culture. If celebrity and fandom are co-reliant, they function by maintaining hierarchy. As Dames suggests, charisma 'is the celebrity's defense against being objectified, a seigneurial right to objectify the other as Observer, as Fan', but Riley would have been unconvinced and uncomforted to learn that this recognition 'also, paradoxically, and yet necessarily, legitimates the recognizer' ${ }^{47}$ Riley's dream - to achieve more than 
'brushes with fame', to become a fellow participant in the production of social change and great writings, and to transcend the construction of celebrity and fan - collided painfully with the realities of a celebrity culture that reflected and policed the hegemony of cultural elites.

\footnotetext{
${ }^{1}$ Henry Salt, Seventy Years Amongst Savages (London: George Allen \& Unwin, 1921), 61-2.

${ }^{2}$ E. T. Cook and Alexander Wedderburn, The Library Edition of John Ruskin's Works, 39 vols. (London: George Allen \& Co, 1903-12), Vol. 25, 207-17.

${ }^{3}$ See Michael Robertson, Worshipping Walt: the Whitman Disciples (Princeton: Princeton University Press, 2008), chapter 5; M. Wynn Thomas, Transatlantic Connections: Whitman
} U.S, Whitman U.K. (Iowa City: University of Iowa Press, 2005), 161-192; Kirsten Harris, “"The "Labour Prophet”?: Representations of Walt Whitman in the British NineteenthCentury Socialist Press', Walt Whitman Quarterly Review 30 (2013), 115-137.

${ }^{4}$ He edited the Leeds Critic (1871) and Herald and Helpmeet (1872-4), the London section journal of the International Working Men's Association, the short-lived Republican Herald (date unknown) and, in Sheffield, The Socialist (1877). Riley's Yankee Letters are referred to in various places, but copies do not appear to exist.

5 Tom Mole's work has been influential within celebrity studies: see Byron's Romantic Celebrity: Industrial Culture and the Hermeneutic of Intimacy (Basingstoke: Palgrave Macmillan, 2007) and Romanticism and Celebrity Culture, 1750-1850 (Cambridge: Cambridge University Press, 2009).

${ }^{6}$ Páraic Finnerty, Anne-Marie Millim, and Charlotte Boyce, Victorian Celebrity Culture and Tennyson's Circle (Basingstoke: Palgrave Macmillan, 2013), 2.

${ }^{7}$ David Haven Blake, Walt Whitman and the Culture of American Celebrity (New Haven: Yale University Press), 2006, 6. 
${ }^{8}$ Leo Braudy, The Frenzy of Renown: Fame and its History (New York: Vintage, 1997);

Brenda R Weber, Women and Literary Celebrity in the Nineteenth Century: the Transatlantic Production of Fame and Gender (Farnham: Ashgate, 2012), 18. See also Judith L. Fisher, "“In the Present Famine of Anything Substantial"; Fraser's "Portraits" and the Construction of Literary Celebrity; or, "Personality, Personality Is the Appetite of the Age", in Victorian Periodicals Review 39.2 (2006), 97-135. On the various categories of fame, see also Dames, Brushes with Fame; and Salmon, 'The Physiognomy of the Lion: Encountering Literary Celebrity in the Nineteenth Century', in Mole, Romanticism and Celebrity Culture.

${ }^{9}$ Richard Salmon, The Formation of the Victorian Literary Professional (Cambridge and New York: Cambridge University Press, 2013), 30.

${ }^{10}$ Nicholas Dames, 'Brushes with Fame: Thackeray and the Work of Celebrity', in Nineteenth-Century Literature 56, 1 (2001), 23-51, 49, 50.

${ }^{11}$ Haven Blake, Walt Whitman, xii.

${ }^{12}$ Walt Whitman, Preface (1872). Complete Poetry and Collected Prose, ed. Edward Havilland Miller, 6 vols (New York: New York University Press, 1961-77), 1002-3; Whitman, 'A Backward Glance o'er Travel'd Roads', in Complete Poetry and Collected Prose, 671.

${ }^{13}$ Robertson, Worshipping Walt, 11.

${ }^{14}$ John Burroughs, 'The Poet of the Cosmos' in Accepting the Universe (New York: William H Wise, 1924), 317.

${ }^{15}$ Robertson, Worshipping Walt, 9, 11.

${ }^{16}$ R. W. Emerson to Whitman, 21 July 1855, in Whitman, Complete Poetry and Collected Prose, 1326. 
${ }^{17}$ William Roscoe Thayer, 'Personal Recollections of Walt Whitman' in Whitman in His Own Time, ed. Joel Myerson (Detroit: Omnigraphics, 1991), 303; Haven Blake, Walt Whitman, xiii.

${ }^{18}$ Robertson, Worshipping Walt, 6, 7; Haven Blake, Walt Whitman, xii. On Whitman and photography, see Haven Blake, 1-5.

${ }^{19}$ On Symons and Wilde, see Robertson, 141, 144-57. It should also be remembered, however, that Whitman's Leaves of Grass was reviewed and discussed in the U.K. a decade earlier: see Charles Ollier's letter to Leigh Hunt, 1856, and various reviews of that year in Gay Wilson Allen and Ed Folsom (eds.), Walt Whitman and the World (Iowa City: University of Iowa Press, 1995), 20-25.

${ }^{20}$ W. H. Riley to W. B. Graham, 6 February 1891, Yale Sterling Memorial Library, MS417.

${ }^{21}$ Riley to unnamed correspondent, 23 October 1876, Rochester University Special Collections.

${ }^{22}$ Whitman, Song of Myself (New York: Roycrofters, 1856), 7-8.

${ }^{23}$ Dames, 'Brushes with Fame', 30; Salmon, Formation of the Victorian Literary Professional, 27. See also Salmon, 'The Physiognomy of the Lion'.

${ }^{24}$ George P. Landow, 'Ruskin as Victorian Sage: the Example of "Traffic”, in New Approaches to Ruskin: Thirteen Essays, ed. Robert Hewison (London, Boston, and Henley: Routledge and Kegan Paul, 1981), 89-90.

${ }^{25}$ John D. Rosenberg, 'Ruskin's Benediction: A Reading of Fors Clavigera' in Hewison (ed.), 127.

${ }^{26}$ Cook and Wedderburn, Library Edition, 27. 369, 354.

${ }^{27}$ See Finnerty, Millim, and Boyce, Victorian Celebrity Culture; Stuart Eagles, Ruskin and Tolstoy (York: Guild of St George, 2010). 
${ }^{28}$ See Mark Frost, The Lost Companions and John Ruskin's Guild of St George: a

Revisionary History (London, New York, and Delhi: Anthem Press, 2014).

${ }^{29}$ W. H. G. Armytage's Heavens Below: Utopian Experiments in England 1560-1960

(London: Routledge and Kegan Paul, 1961), 291-298, is largely responsible for the

widespread misrepresentation of Riley. See Frost, Lost Companions, 158-73.

${ }^{30}$ Pierpont Morgan Library, MA2457.44.

${ }^{31}$ Many such editions were published in London by Thomas Wise. See Letters Upon Subjects of General Interest from John Ruskin to Various Correspondents (London: Thomas J. Wise, 1892); Letters From John Ruskin to Rev. J. P. Faunthorpe, M.A., 2. vols. (London: Thomas J. Wise, 1895-6); Letters from John Ruskin to Rev. F. A. Malleson, M.A., Vicar of Broughton in Furness (London: Thomas J. Wise, 1896); Letters from John Ruskin to Frederick J.

Furnivall, M.A., Hon. Dr. Phil. and other Correspondents (London: Thomas J. Wise, 1897).

${ }^{32}$ John Ruskin to Riley, 13 October 1873, 27 March [1874?], and 23 December [1874?], New York Public Library, Montague Collection, Box 8; Yale Sterling Memorial Library, MS417.

${ }^{33}$ Ruskin to Riley, 13 October 1873, New York Public Library, Montague Collection.

${ }^{34}$ See Frost, Lost Companions, 133-43, 158-60.

${ }^{35}$ Riley to unnamed correspondent, 22 May 1879, Rochester University Special Collections, Sidney Ross Collection.

${ }^{36}$ Riley to Graham, 15 February 1889, Wellesley Special Collections, Ruskin Collection, MS 1887-9.

${ }^{37}$ Riley to unnamed correspondent, 22 May 1879. Rochester University Special Collections. ${ }^{38}$ In 'The English Whitman', in Transatlantic Connections: Whitman U.S, Whitman U.K. (Iowa City: University of Iowa Press, 2005), 161-192, M. Wynn Thomas argues that Carpenter's poetic works were part of a wider movement to 'translate' Whitman's ideas into a British context. See also Kirsten Harris, “"The "Labour Prophet”?: Representations of Walt 
Whitman in the British Nineteenth-Century Socialist Press', Walt Whitman Quarterly Review 30 (2013), 115-137; and Robertson, Worshipping Walt, Chapter 5.

${ }^{39}$ Riley to Whitman, 5 March 1879, New York Public Library, Berg Collection, 225063B.

${ }^{40}$ Cook and Wedderburn, Library Edition, 27. 170.

${ }^{41}$ A few years later, as a result of another Ruskin-related enquiry, Whitman spent only a few moments dashing off a weary letter of instruction to a colleague. See Whitman to William O’Connor, 22 September 1882, New York Public Library, Berg Collection, 225063B.

${ }^{42}$ Riley to Whitman, 2 April 1879 (1), New York Public Library, Berg Collection, 225063B.

${ }^{43}$ Whitman was dismissed from a post with the Department of the Interior in 1865, but almost immediately appointed to a better post with the Attorney General (Robertson 32-3). ${ }^{44}$ Riley to Whitman, 2 April 1879 (2), New York Public Library, Berg Collection, 225063B. ${ }^{45}$ Riley to Graham, 15 February 1889, Wellesley Special Collections, Ruskin Collection, MS 1887-9.

${ }^{46}$ W. J. Bathgate to Whitman, 31 January 1880, New York Public Library, Berg Collection, 225063B. Ruskin's comment were reported in the Athenaeum, 20 March 1880. There are no references to Whitman in Ruskin's published writings.

${ }^{47}$ Dames, 'Brushes with Fame', 34. 